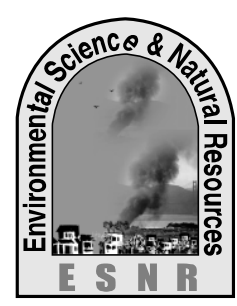

\title{
Investigation of Water Quality Parameters from Ramna, Crescent and Hatirjheel Lakes in Dhaka City
}

\author{
M. S. Islam*, M. Rehnuma, S. S. Tithi, M. H. Kabir and L. Sarkar ${ }^{1}$ \\ Department of Environmental Science and Resource Management, \\ Mawlana Bhashani Science and Technology University, Tangail-1902 \\ ${ }^{1}$ Department of Environmental Technology, Khulna Polytechnic Institute, Khulna-9000 \\ *Corresponding author: islammstazu@yahoo.com
}

\begin{abstract}
The study was conducted to know the status of water quality of the Ramna, Crescent and Hatirjheel lakes in the Dhaka city. Water samples were collected from three different points of each lake and analyzed for various physicochemical parameters including temperature, $\mathrm{pH}, \mathrm{EC}$, TDS, DO, BOD, hardness, alkalinity, acidity during the period from November 2013 to April 2014. The mean temperature $22.54,24.59$ and $24.24^{\circ} \mathrm{C}$; EC $15400,282.00$ and $618.27 \mu \mathrm{Scm}^{-1}$; TDS $85.38,155.60$ and 339.90 ppm; pH 7.73, 7.85 and 7.67; DO 3.51, 3.92 and 3.65 ppm; BOD 0.93, 0.73 and 3.15 ppm; hardness 95.00, 108.56 and $105.11 \mathrm{ppm}$; alkalinity 48.9, 120.7 and $249.1 \mathrm{ppm}$, and acidity 2.18, 2.67 and $2.05 \mathrm{ppm}$ were investigated from Ramna, Crescent and Hatirjheel lakes, respectively. Lower concentration of DO was observed in all three lakes that severely harmed the aquatic organisms and degrade their habitat. The comparative study demonstrated that the concentration of BOD, EC, TDS, alkalinity and acidity of Hatirjheel Lake was higher than Ramna and Crescent lakes which indicated pollution of the lake water. The rain and storm water runoff, lack of awareness of people were responsible for the pollution of Ramna, Crescent and Hatirjheel lakes water. Connection of the sewerage line with the rain water collection channels and mixing of solid waste with lake water are the main reasons for pollution of Hatirjheel lake. Poor water quality of these lakes affects the ecosystem and aesthetic beauty negatively. To maintain the sound environment and healthy ecosystem of the lakes and the surrounding areas need proper management and monitoring and implementation of existing laws and regulations. Moreover public awareness is necessary otherwise it is hardly possible to maintain sound water quality of these three lakes.
\end{abstract}

Key words: Crescent, Hatirjheel, Ramna, Water pollution

\section{Introduction}

The main sources of water in Bangladesh are surface waters in rivers, reservoirs, lakes, canals and ponds, and groundwater in shallow and deep aquifers (Ahmed and Rahman, 2005). The country's surface water resource is very much essential for its human and animal living, aquatic flora and fauna, navigation, agriculture, etc. But the quality of water is deteriorated day by day primarily due to the decomposition of municipal, domestic, industrial, and agricultural wastes (Todd, 1980). Thus, surface water monitoring is essential for aquatic resource management (Haque, 2008). Lakes are one of the most potential water resources that can meet the increasing demand of water throughout the Dhaka city in dry seasons. They act as water retention basins during the monsoon and besides being the sources of biodiversity of the area; they are an important part of the scenic beauty. But water quality is deteriorated day by day due to numerous biological, physical and chemical variables causing water toxicity. Due to excessive population pressure, unawareness and lack of enforcement of legal actions, very few water bodies retain good water quality and biodiversity. Pollution and contamination of the lakes water have negative impacts on the aquatic resources. Tannery and other industrial wastes, unplanned sewage system, medical wastes, nuclear and toxic materials mixing with drain water passes to lakes and thus polluting lake waters (Abadeen, 2002). Hatirjheel, Crescent and Ramna Lakes are the part of long demand of the urban dwellers for their physical as well as mental nourishment and are the shiniest areas in Dhaka city. But water of these artificial lakes are abused by dumping solid wastes, discharging waste water and sewages that hardly any emergency water requirement need can be met with this water. Waste water from different adjoining areas are released in the Hatirjheel canals and mixed with the rain water and made it difficult to keep the water clean. In the study, the water quality parameters were investigated from, Ramna, Crescent and Hatirjheel Lakes and compared with relevant standard levels to know the present status of water quality of the lakes.

\section{Materials and Methods}

\section{Study area}

The study was conducted at Ramna, Crescent and Hatirjheel Lakes in Dhaka city for a period of six month from November 2013 to April 2014. Ramna Lake is situated in Ramna thana and it is a part of the Ramna park. The area of Ramna Park is $277209.64 \mathrm{~m}^{2}$. In 1949 Ramna Lake was made. Institute of Engineering (IEB) is in the south-east of Ramna Lake where Shishu park is situated in the southwest. Maximum portion of the park is in the north-west part. The area of Ramna Lake is 8.76 acre. Its width varies from 9-94 $\mathrm{m}$ to some points and the lake is $812 \mathrm{~m}$ long (Razzak et al., 2013). Crescent Lake is part of Chandrima Uddan which was approximately within latitude $23^{\circ} 45^{\prime} 53^{\prime \prime} \mathrm{N}$ and longitude $90^{\circ} 22^{\prime} 43^{\prime \prime} \mathrm{E}$. Crescent Lake is situated in the road beside the Jatiyo Sangshad Bhaban in Dhaka (Razzak et al., 2013). Hatirjheel is located at the centre of the capital, Dhaka. It has latitude of 
$23^{\circ} 44^{\prime} 58.47^{\prime \prime} \mathrm{N}$ and longitude of $90^{\circ} 23^{\prime} 48.35^{\prime \prime} \mathrm{W}$. The place is surrounded by Tejgaon, Gulshan, Badda, Rampura, Niketon, Maghbazar, etc. (Mokaddes et al., 2013).

\section{Sample collection}

The water samples were collected from three sites of each lake during November 2013 to April 2014 where November 2013 to January 2014 was considered as post-monsoon and February to April 2014 was considered as pre-monsoon season. Plastic bottles with stopper having a volume of 500 $\mathrm{ml}$ each and marked with lake's name and sampling point were used for collection of water samples. Before collection of water samples bottles were cleaned and washed with detergent solution. Then the sampling bottles rinsed with deionized water and dried. After sampling, bottles were screwed carefully and marked with the respective identification number. Necessary information for each sample such as date of collection, location, time of collection was recorded in note book. Simple random sampling was used for the primary data collection.

\section{Sample analysis}

The water quality parameters such as temperature and $\mathrm{pH}$ were determined by the thermometer and digital $\mathrm{pH}$ meter (model- $\mathrm{pH}$ Scan WP 1, 2, Malaysia), respectively. The electrical conductivity (EC) and total dissolved solid (TDS) was measured by digital EC meter (model-HM digital, Germany) and digital TDS meter, respectively. Dissolved oxygen was determined by digital DO meter. Alkalinity and acidity were measured by titration method and EDTA method was used to determine the hardness of sample water. The BOD was measured by two steps where initial BOD $\left(\mathrm{BOD}_{1}\right)$ was measured immediately after collection and after 5 days BOD $\left(\mathrm{BOD}_{5}\right)$ was measured by incubation in the dark condition at $20^{\circ} \mathrm{C}$ for 5 days. Then the total BOD $\left(\mathrm{BOD}_{1}-\mathrm{BOD}_{5}\right)$ was measured according to Trivedy and Goel (1984), and Huq and Alam (2005).

\section{Statistical analysis}

The collected data were analyzed by using the software MS Excel. The findings of the study were presented as chart and tabular forms.

\section{Results and Discussion}

The colors of the investigated lakes water were observed visually. The observed color were light green in Ramna and Crescent lakes and color of Hatirjheel lake water was found to vary from dark greenish blue to brown. Light green color represented lower planktons. The dark greenish blue and brown color represented higher planktons. According to Das (1997) a well and phytoplankton enriched water body appears to be dark greenish blue, red and brown. Higher plankton concentration sometime responsible for blooming which results less oxygen in water and more carbon dioxide. The odors of the investigated lakes water were smelt by nose. The odor of Ramna and Crescent lakes were found to vary from odorless to bad odor and for Hatirjheel lake water foul odor was found.

Temperature of the investigated lakes water found to be more or less similar at different months. Temperature recorded ranging from 19.78 to 29.5 , 19.56 to 29.53 and 19.53 to $29.7{ }^{\circ} \mathrm{C}$ in Ramna, Crescent and Hatirjheel lakes, respectively (Table 1). Maximum temperature was found in the month of April and minimum temperature was found in February for all the three lakes. Temperature of the lakes water was just below $30^{\circ} \mathrm{C}$ which was within the standard limit (Table 2). The EC concentrations were ranged from 113 to $181.7,190$ to 342.6 and 500 to $730.7 \mu \mathrm{S} / \mathrm{cm}$ in Ramna, Crescent and Hatirjheel lakes, respectively (Table 1). Lower EC content was recorded during post monsoon season and higher conductivity was recorded in premonsoon season. The maximum EC concentration was in Hatirjheel Lake and minimum was in Ramna lake. Concentration of EC in Hatirjheel lake was higher than the Ramna and Crescent lakes and also greater than standard values (Table 2) of ADB (1994).

The study revealed that TDS concentrations were found to ranging from 78.66 to $94.00,129.30$ to 176.66 and 326.33 to $380.67 \mathrm{ppm}$ in Ramna, Crescent and Hatirjheel lakes, respectively (Table 1). The TDS concentration of Hatirjheel lake exceeded the standard value (165 ppm) of Huq and Alam (2005) which indicates the presence of an appreciable quantity of bicarbonates, sulphates and chlorides of $\mathrm{Ca}, \mathrm{Mg}$ and $\mathrm{Na}$. A positive relation was found between EC and TDS where the EC concentration increased with increasing the TDS concentration. The ranges of variation in $\mathrm{pH}$ were from 7.14 to $8.87,7.30$ to 8.83 and 7.12 to 8.76 in Ramna, Crescent and Hatirjheel lakes, respectively (Table 1). The mean $\mathrm{pH}$ of all the three lakes water were within the standard limit. But the $\mathrm{pH}$ of all the three lakes exceeded standard limit in month of April (Table 1).

The average concentrations of Dissolved Oxygen (DO) were found to vary from 2.6 to $5.11,2.96$ to 5.3 and 1.6 to $3.6 \mathrm{ppm}$ in Ramna, Crescent and Hatirjheel lakes, respectively (Table 1). The concentration of DO was found to be higher during post-monsoon season compared with pre- monsoon season in all the studied lakes. Adequate DO is necessary for good water quality, survival of aquatic organism and decomposition of waste by microorganism (Islam et al., 2010). The alarming condition of the studied lakes water in case of DO was observed which is detrimental for aquatic organism. The DO concentration of Ramna, 
Crescent and Hatirjheel lakes water indicated that the quality of water was poor and detrimental for fisheries. The maximum DO concentration was in Crescent and minimum was in Hatirjheel lake.

Table 1. Water quality parameters of Ramna, Crescent and Hatirjheel lakes during the study period

\begin{tabular}{|c|c|c|c|c|c|c|c|c|}
\hline \multirow{2}{*}{ Parameter } & \multirow{2}{*}{ Location } & \multicolumn{7}{|c|}{ Months } \\
\hline & & Nov. & Dec. & Jan. & Feb. & Mar. & Apr. & Mean \pm SD \\
\hline \multirow{3}{*}{$\begin{array}{l}\text { Temperature } \\
\left({ }^{\circ} \mathrm{C}\right)\end{array}$} & Ramna & 22.4 & 25.6 & 20.6 & 19.7 & 21.7 & 29.5 & $22.54 \pm 3.52$ \\
\hline & Crescent & 23.5 & 26.6 & 21.7 & 20.5 & 25.7 & 29.6 & $24.59 \pm 3.32$ \\
\hline & Hatirjheel & 25.4 & 25.5 & 20.7 & 19.5 & 24.6 & 29.7 & $24.24 \pm 3.68$ \\
\hline \multirow{3}{*}{$\begin{array}{c}\mathrm{EC} \\
(\mu \mathrm{S} / \mathrm{cm})\end{array}$} & Ramna & 120.0 & 113.3 & 164.6 & 168.3 & 176.0 & 181.7 & $154.0 \pm 5.35$ \\
\hline & Crescent & 190.0 & 203.3 & 315.7 & 316.0 & 329.3 & 342.6 & $282.0 \pm 67.6$ \\
\hline & Hatirjheel & 500.0 & 500.0 & 709.3 & 719.6 & 730.7 & 558.0 & $618.2 \pm 112.0$ \\
\hline \multirow{3}{*}{$\begin{array}{l}\text { TDS } \\
(\mathrm{ppm})\end{array}$} & Ramna & 78.66 & 81.0 & 85.0 & 86.33 & 87.30 & 94.0 & $85.3 \pm 5.35$ \\
\hline & Crescent & 129.3 & 146.3 & 161.3 & 158.6 & 161.67 & 176.6 & $155.6 \pm 16.1$ \\
\hline & Hatirjheel & 326.3 & 357.7 & 360.3 & 362.6 & 352 & 380.7 & $339.9 \pm 31.9$ \\
\hline \multirow{3}{*}{$\mathrm{pH}$} & Ramna & 7.73 & 7.61 & 7.52 & 7.14 & 7.54 & 8.87 & $7.73 \pm 0.59$ \\
\hline & Crescent & 7.91 & 7.33 & 7.30 & 7.84 & 7.86 & 8.83 & $7.85 \pm 0.55$ \\
\hline & Hatirjheel & 7.83 & 7.12 & 7.18 & 7.39 & 7.71 & 8.76 & $7.67 \pm 0.60$ \\
\hline \multirow{3}{*}{$\begin{array}{c}\mathrm{DO} \\
(\mathrm{ppm})\end{array}$} & Ramna & 5.11 & 2.60 & 4.10 & 3.23 & 3.46 & 2.60 & $3.51 \pm 0.96$ \\
\hline & Crescent & 5.30 & 3.83 & 4.10 & 3.73 & 3.60 & 2.96 & $3.92 \pm 2.51$ \\
\hline & Hatirjheel & 2.36 & 3.60 & 3.23 & 2.26 & 3.03 & 1.60 & $2.68 \pm 0.75$ \\
\hline \multirow{3}{*}{$\begin{array}{l}\text { BOD } \\
(\mathrm{ppm})\end{array}$} & Ramna & 0.43 & 1.03 & 0.86 & 1.47 & 0.93 & 0.87 & $0.93 \pm 0.45$ \\
\hline & Crescent & 0.33 & 0.73 & 0.37 & 0.93 & 1.06 & 0.96 & $0.73 \pm 0.15$ \\
\hline & Hatirjheel & 3.60 & 2.10 & 2.70 & 3.10 & 3.40 & 4.00 & $3.15 \pm 0.60$ \\
\hline \multirow{3}{*}{$\begin{array}{l}\text { Hardness } \\
\text { (ppm) }\end{array}$} & Ramna & 130.0 & 110.0 & 113.3 & 96.6 & 76.7 & 43.3 & $95.0 \pm 30.0$ \\
\hline & Crescent & 226.0 & 136.7 & 83.3 & 97.3 & 103.4 & 53.2 & $108.5 \pm 105.1$ \\
\hline & Hatirjheel & 98.0 & 119.3 & 100.0 & 126.6 & 143.3 & 43.3 & $105.1 \pm 60.2$ \\
\hline \multirow{3}{*}{$\begin{array}{l}\text { Alkalinity } \\
\text { (ppm) }\end{array}$} & Ramna & 66.6 & 59.3 & 60.7 & 30.0 & 31.6 & 45.0 & $48.9 \pm 15.6$ \\
\hline & Crescent & 97.3 & 150.0 & 176.0 & 83.3 & 105.0 & 112.5 & $120.7 \pm 35.1$ \\
\hline & Hatirjheel & 253.3 & 274.0 & 300.0 & 96.67 & 183.3 & 387.5 & $249.1 \pm 99.9$ \\
\hline \multirow{3}{*}{$\begin{array}{l}\text { Acidity } \\
\text { (ppm) }\end{array}$} & Ramna & 1.9 & 1.8 & 2.5 & 2.9 & 2.0 & 1.7 & $2.1 \pm 0.5$ \\
\hline & Crescent & 1.6 & 1.0 & 5.9 & 2.0 & 1.7 & 3.7 & $2.6 \pm 1.8$ \\
\hline & Hatirjheel & 3.5 & 3.1 & 9.5 & 7.8 & 5.4 & 0.8 & $5.0 \pm 3.2$ \\
\hline
\end{tabular}

Note: $S D=$ Standard deviation

Table 2. Comparison of water quality parameters among Ramna, Crescent, Hatirjheel lakes and with standard

\begin{tabular}{lcccc}
\hline Parameters & Ramna lake & Crescent lake & Hatirjheel lake & Standard \\
\hline Temperature $\left({ }^{\circ} \mathrm{C}\right)$ & 22.54 & 24.59 & 24.24 & $20-30(\mathrm{EQS}, 1997)$ \\
$\mathrm{EC}(\mu \mathrm{s} / \mathrm{cm})$ & 154 & 282 & 618.27 & $500(\mathrm{ADB}, 1994)$ \\
$\mathrm{pH}$ & 7.73 & 7.85 & 7.67 & $6.5-8.5(\mathrm{De}, 2005)$ \\
DO $(\mathrm{ppm})$ & 3.51 & 3.92 & 2.68 & $5(\mathrm{EQS}, 1997)$ \\
Hardness $(\mathrm{ppm})$ & 95 & 108.56 & 105.11 & $123(\mathrm{Hud}$ and Alam. 2005) \\
Alkalinity $(\mathrm{ppm})$ & 48.9 & 120.7 & 249.13 & $>100($ Rahman, 1992) \\
\hline
\end{tabular}

The concentrations of BOD were within ranges from 0.43 to $1.46,0.33$ to 0.93 and 2.10 to 4.00 ppm, respectively in Ramna, Crescent and Hatirjheel lakes (Table 1). The concentrations of BOD were found to be higher during pre monsoon season than post-monsoon season in studied lakes. According to ECR (1997), standard of BOD for drinking water is 2 or less than $2 \mathrm{ppm}$. The BOD concentration of Hatirjheel lake exceeded the drinking water quality standards (DoE, 1997). When BOD level is high, DO level decrease because the oxygen available in water is consumed by bacteria (Sawyer et al., 1994). The maximum BOD concentration was in Hatirjheel lake and minimum was in Crescent lake (Fig. 1).

The hardness of water samples were found to vary from 43.3 to $130.0,53.2$ to 226.0 and 43.3 to 143.3 ppm, respectively in Ramna, Crescent and Hatirjheel lakes (Table 1). Hardness of studied lakes water was comparatively higher in postmonsoon than the pre-monsoon season. Water of 
the studied lakes was moderately hard. According to Swingle (1967) a total hardness of $15 \mathrm{ppm}$ or more is suitable for fish culture. The maximum TDS concentration was in Hatirjheel lake and minimum was in Ramna lake (Fig. 2).

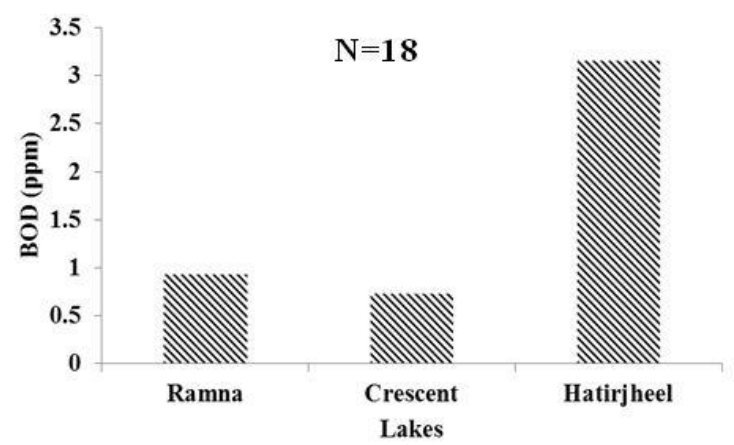

Fig. 1. Comparison of BOD concentrations among Ramna, Crescent and Hatirjheel lakes

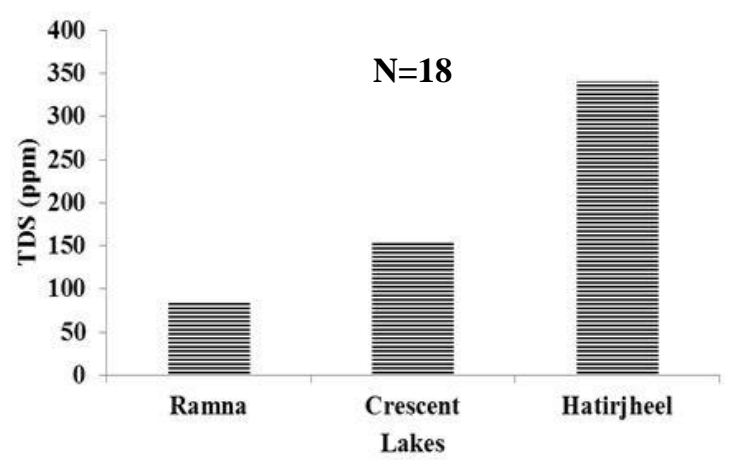

Fig. 2. Comparison of TDS concentrations among Ramna, Crescent and Hatirjheel lakes

The alkalinity of Ramna, Crescent and Hatirjheel lake water was ranged from 30.00 to $66.67,83.33$ to 112.50 and 96.67 to $387.50 \mathrm{ppm}$, respectively (Table 1). The alkalinity of Ramna lake water was lower than standard value (Table 2). The acidity of Ramna, Crescent and Hatirjheel lake water was ranged from 1.70 to $2.91,1.08$ to 5.91 and 0.83 to $9.50 \mathrm{ppm}$, respectively (Table 1). Acidity of Hatirjheel lake water was found to be higher than Ramna and Crescent lakes.

\section{References}

Abadeen, M. J. 2002. Industrial waste water. Give earth a chance. World Environment Day Report, Department of Environment, the Government of Bangladesh.

ADB (Asian Development Bank). 1994. Training Manual for Environmental Monitoring. Engineering Science Incorporation, USA. pp. 226.

Ahmed, M. F. and Rahman, M. M. 2005. Water supply and sanitation, Rural and low income urban communities. ITN-Bangladesh, Center for water supply and waste management, BUET, Dhaka, Bangladesh.

\section{Conclusions}

From the investigation of water quality of the three lakes, it was observed that water of the Hatirjheel lake was severely polluted compared to the Ramna and Crescent lake. Water of Ramna and Crescent lakes were polluted mainly by visitation activity. Most of the visitors do not apply civic sense when they go to the study area. They carry with them soft drinks bottles, polythene filled with ground nut, biscuits and newspaper and leave those there after use. Since those are not removed, environment gets polluted. People also pollute water by bathing and washing clothes on the lakes. Mixing of waste water lines with the rain water inside Hatirjheel is the main reason of pollution. Waste water from different adjoining areas are released in the Hatirjheel canals and mixed with the rain water and made it difficult to keep the water clean. When it rains, solid waste mixed with it enters the Hatirjheel lake and thereby, pollutes the lake water. To recover the soundness of aquatic environment of the lakes, it is necessary to prevent or reduce processes which degrade or pollute lake water quality (storm water flow, sanitary water flow, stock piling of construction debris and solid wastes, unauthorized construction works in the vicinity of lake area, etc.), to create monitoring and maintenance cell, creating public awareness, preventing and controlling harmful discharges.

\section{Acknowledgements}

The authors acknowledge all of officials and laboratory staffs of the Department of Environmental Science and Resource Management, Mawlana Bhashani Science and Technology University, Tangail, Bangladesh for their kind cooperation and technical supports during the research period.

Das, B. 1997. Fisheries and fisheries resources management. Bangla Academy, Dhaka, Bangladesh. pp. 153-155.

De, A. K. 2005. Environmental chemistry. Fifth Edition, New Age International (Pvt.) Ltd., Daryagang, New Delhi, India. p.187.

DoE (Department of Environment). 1997. Environmental quality standard for Bangladesh.

ECR (Environment Conservation Rules). 1997. Ministry of Environment and Forest, Government of the People's Republic of Bangladesh. pp. 205-207. 
EQS (Environmental Quality standard). 1997. Bangladesh Gazette, registered nr. DA-1, Ministry of Environment, Government of Bangladesh, pp.26-108.

Haque, M. I. 2008. Water resources management in Bangladesh. Anushila, Chuadanga and Dhaka, pp. 24-84.

Huq, S. M. I. and Alam, M. D. 2005. A handbook on analysis of soil, plant and water. BACERDU, University of Dhaka. Bangladesh.

Islam, M. S.; Suravi and Meghla, N. T. 2010. Investigation of water quality in Ashulia beel, Dhaka, Bangladesh. Journal of Fisheries Research, 14(1-2): 55-64.

Mokaddes, M. A. A.; Nahar, B. S. and Baten, M. A. 2013. Status of heavy metal contaminations of lake water of Dhaka Metropolitan City. Journal of Environmental Science and Natural Resources, 6(1): 345-348.

Rahman, M. S. 1992. Water quality management in aquaculture. BRAC Prokashana, Bangladesh. p. 84.
Razzak, N. R. B.; Muntasir, S. Y and Chowdhury, S. 2012. Pollution scenario of Dhaka city lakes: a case study of Dhanmondi and Ramna lakes. Global Engineers and Technologist Review, 2(7): 1-6.

Razzak, N.R.B.; Siddik, A. Z. and Ahmeduzzaman, M. 2013. Evaluation of water quality of Ramna and Gulshan lakes. International Journal of Environmental Monitoring and Analysis, 1(6): 273-278.

Sawyer, C. L.; McCarty, P. L. and Parkin, G. E. 1994. Chemistry for environmental engineering, Fourth edition, McGraw Hill, Inc., New York.

Swingle, H. S. 1967. Standardization of chemical analysis for waters and pond muds. FAO Fish Report, 4(44): 397-421.

Todd, D. K. 1980. Ground water hydrology. Second edition. John Willey and Sons' Inc.

Trivedy, R. K. and Goel, P.K. 1984. Chemical and biological methods for water pollution studies. Environmental publications, KARAD, pp. 4274. 